W ogólnym rozrachunku koncepcja książki jest klarowna. Poza oczywistymi walorami naukowymi, na uwagę zasługują niewątpliwie walory edytorskie oraz graficzne publikacji, na które składa się m.in. szeroka baza ilustracji. Wszelka poruszana przez Kamillę Łozowską-Marcinkowską problematyka czasopism kobiecych Drugiej Rzeczypospolitej, dostarcza czytelnikowi ogromu uporządkowanych informacji, przedstawionych w sposób jasny i przystępny. Liczne cytaty zawarte w tekście nadają książce niepowtarzalną formę. Bogata bibliografia zamieszczona na końcu książki, zawierająca źródła i opracowania, pozwoli czytelnikowi zgłębić wiedzę poruszonej przez Autorkę problematyki. Pracę wieńczy spis ilustracji zaczerpniętych z analizowanych czasopism.

Książka jest istotnym wkładem w budowanie świadomości, że czasopisma, nie tylko kobiece, stanowią obszerne źródło wiedzy. Efektem analizy zawartości tematycznej piśmiennictwa kobiecego dwudziestolecia międzywojennego są licznie interesujące wnioski i tezy, które stawia w toku rozważań Autorka i które systematyzuje w zakończeniu książki. Ponadto, Autorka w zdecydowanej większości nie opiera się na gotowych opracowaniach, lecz odwołuje się przede wszystkim do źródeł, co ważne, umiejętnie posługuje się wiedzą ogólną w historycznym kontekście pracy.

Publikacja Kamilli Łozowskiej-Marcinkowskiej Sprawy niewieście. Problematyka czasopism kobiecych Drugiej Rzeczypospolitej zasługuje na uwagę szerokiego grona czytelników mimo naukowego charakteru.

Konrad Nowak-Kluczyński

\title{
Dorota Żołądź-Strzelczyk pt. Szkoły w Wielkopolsce - od średniowiecznych początków do reform Komisji Edukacji Narodowej, Wydawnictwo Poznańskie 2010, sS. 324
}

Książka pióra wybitnej badaczki specjalizującej się w historii edukacji staropolskiej wpisuje się w krąg dzieł poświęconych dziejom oświaty, myśli i kultury intelektualnej. Autorka rzetelnie wykorzystała dobrze dobrane publikacje. Doceniła dorobek wielu pokoleń uczonych rodzimych i obcych - sięgnęła do klasycznych opracowań oraz uwzględniła najnowsze studia humanistyki polskiej.

Skrupulatnie prezentowane przez Autorkę programy nauczania (często po raz pierwszy wprowadzane do obiegu naukowego) są poznawczo cenne, opatrzone solidnym komentarzem i odniesieniami do przemian kultury umysłowej w omawianych epokach, dyskusją nad intelektualnymi sądami wybitnych badaczy. Programy i ich wykładnia z pewnością zachęcą badaczy do dalszych studiów komparatystycznych.

Autorka doceniła oświatę protestancką (nie uczynił tego w swej ostatniej książce Stanisław Janeczek, Edukacja oświeceniowa a szkoła tradycyjna. Z dziejów kultury intelektualnej i filozoficznej, Wydawnictwo KUL, Lublin 2008). Dorota Żołądź-Strzelczyk ma 
świadomość, że w krajach i obszarach, gdzie zwyciężył protestantyzm, kontrolę nad edukacyjnymi przemianami przejęli świeccy - królowie, książęta oraz władze miast. Czołowe placówki luterańskie znacznie szybciej niż katolickie dostosowywały swój profil do oczekiwań społecznych. Przykład stanowią, wspierane organizacyjnie i finansowo przez rady miast, gimnazja w Prusach Królewskich Rzeczypospolitej. Badaczka celnie zauważyła, że na strukturę i program tych szkół wywierała wpływ przede wszystkim kultura protestancka - elitarna, erudycyjna i otwarta na nowe prądy filozoficzne i naukowe, płynące głównie z Niemiec i Niderlandów.

Autorka celnie wyeksponowała podobieństwa i różnice między modelem szkół katolickich i protestanckich. Te cenne wątki uwydatniła również w zakończeniu. Można przyznać rację Autorce, że kolegia jezuickie istotnie dawały znaczny zasób wiedzy ogólnej. Adaptując selektywnie cenione dziedzictwo antyku, oddalały się jednak coraz bardziej od osiągnięć świata nauki i kultury. Erudycja nie mogła przecież w pożądanym stopniu ogarnąc rozwijających się i usamodzielniających się dyscyplin. Ratio studiorum z 1599 r. pomijała historię, politykę, prawo i języki nowożytne oraz kunszty rycerskie cenione w edukacji elit. Szkoły jezuitów, przyjęte przez elitarną klientelę zrazu z zadowoleniem, z czasem stawały się dla niej mniej atrakcyjne, wręcz archaiczne.

Autorka słusznie twierdzi, że nauczyciele jezuiccy nie traktowali dorobku starożytnych twórców jako źródła ułatwiającego zrozumienie antycznej cywilizacji. Rzeczywiście, pozostając na usługach Towarzystwa, stawał się on głównie przykładem właściwego stylu. Odmienny stosunek do tej spuścizny prezentował Francesco Petrarka, który nie wykorzystywał tekstów starożytnych do potwierdzenia własnych przekonań, lecz usiłował możliwie wiernie odtworzyć oraz zrozumieć odmienność minionego i fascynującego świata.

W kanonie lektur szkół protestanckich Dorota Żołądź-Strzelczyk wskazała na wagę obecności dzieł Erazma z Rotterdamu (jak wynika ze żmudnych, źródłowych dociekań Autorki, Erazma czytano nawet w szkole Jednoty w Koźminku) i brak tych prac w szkołach katolickich. Wydaje się, że ten cenny wątek szczególnie zainteresuje badaczy dziejów oświaty nie tylko wielkopolskiej.

Obraz działalności rodzimych placówek oświatowych w polskiej historiografii zbyt często wypacza niedostateczne uwzględnianie przemian w nauce i szkolnictwie zachodnioeuropejskim. Przyznać trzeba, że Dorota Żołądź-Strzelczyk, przedstawiając szkoły Wielkopolski, bardzo umiejętnie ukazała dynamiczne przemiany edukacyjne, które nastąpiły nieco wcześniej w Europie. Całość problematyki ujęła panoramicznie i przejrzyście. Autorka analizowała sposób funkcjonowania szkół Wielkopolski w odniesieniu do europejskich tradycji kształcenia elit. Poruszyła przy tym kwestię miejsca, które zajmowali w nauczaniu jezuickim czy protestanckim autorzy starożytni, dzięki czemu monografia stanowi interesującą lekturę dla filologów klasycznych - tym cenniejszą, że znajomość tego rodzaju tematyki niezbędna jest zwłaszcza neolatynistom. Dorota Źołądź-Strzelczyk omawia na przykład rolę literatury i historii antycznej jako skarbnicy wzorców parenetycznych oraz status łaciny jako języka integrującego szlachtę Rzeczypospolitej (fenomen Latinitas). Przedstawia autorów, których czytano w kolegiach, i wskazuje na tworzenie się pewnego kanonu na poszczególnych etapach kształcenia, obejmującego teksty Neposa, 
Liwiusza, Horacego oraz Owidiusza, a nade wszystko Cycerona, traktowanego jako mistrza sztuki wymowy. Z pracy wyłania się wizja sztuki oratorskiej jako kompetencji niezwykle istotnej - w jej upadku widziano zagrożenie dla dobra publicznego. Monografia stanowi bogate źródło wiedzy na temat drogich nie tylko badaczom antyku czasów, gdy nauczyciele kierowali się formułą: Et pie vivant et Latine Loquantur. Studia Doroty Żołądź-Strzelczyk potwierdzają tezę o ogromnej roli szkół luterańskich i katolickich w przekazywaniu dziedzictwa kulturowego antyku.

Wiek XVIII stanowił okres wiary w naukę, jej zastosowanie i konieczność upowszechniania osiągnięć poszczególnych dyscyplin. Jakkolwiek częściej pojawiały się teksty pozbawione magicznego słowa imprimatur, nie można jednak, jak słusznie zauważa Autorka, mówić o daleko idącej akceptacji nowych idei w szkołach wyznaniowych. Spory mieszczaństwa z Kościołem były trwałym elementem wpływającym na treści i ich wykładnię. W recenzowanej rozprawie ten wątek słusznie przewija się w prezentacji dziejów szkół Wielkopolski od średniowiecza aż do czasów Komisji Edukacji Narodowej. Na uwagę zasługuje obecny w rozprawie wątek dotyczący trudnego statusu zdolnych, twórczych i otwartych na nowe prądy naukowe pedagogów w szkołach katolickich i różnowierczych.

Organizacja, misja i program szkół średniowiecznych miały swoje korzenie i długie trwanie. Autorka w swej rozprawie wielokrotnie akcentuje przejawy ciągłości czy też zawirowań. Warto zauważyć, że badacze dostrzegają złotą jesień średniowiecza, w renesansie z coraz większą uwagą spoglądają na długie trwanie Pochwały głupoty Erazma z Rotterdamu, a w oświeceniu, wieku świateł, widzą próg naszej współczesności (Teresa Kostkiewiczowa). Należy mieć nadzieję, że studium Doroty Żołądź-Strzelczyk przyczyni się do ożywienia dysputy nad tematem przedstawionym w tytule książki, a zarazem nad polskim głosem w edukacyjnej ofercie omawianych stuleci.

Dorota Żołądź-Strzelczyk dostrzegła nie tylko osiągnięcia oświaty protestanckiej, ale także to, że niedostatki szkół katolickich wynikały nie tyle z mentalności, bierności i braku aspiracji elit społecznych czy państwa, co z autonomicznej polityki edukacyjnej poszczególnych zakonów i zgromadzeń ponadnarodowego Kościoła. Śmielsze wysiłki zmierzające do unowocześnienia nauczania były w większości udaremniane przez przełożonych, a także przez oportunizm i konserwatyzm własnego środowiska. Autorka celnie dodała jednak, iż poznańskie kolegium jezuitów stanowiło udany przykład modyfikacji placówek tego zgromadzenia. Istotnie, zakon Loyoli, by wychować wiernych synów Kościoła oraz zachować wpływ na kształcenie możnych i rządzących, starał się pogodzić własny konserwatyzm z aspiracjami światłych elit. Efekt tego kompromisu stanowiło poznańskie elitarne kolegium dla szlachty, gdzie wykładał m.in. Jan Bielski, Michał Kociełkowski i Józef Rogaliński. Jak się wydaje, nie tylko podstawy materialne stanowiły o znaczeniu poszczególnych szkół, ale i doświadczenie, talent wykładowców, a nade wszystko siła osobowości przełożonych. Przykładem może być właśnie profesor kolegium szlacheckiego w Poznaniu, Józef Rogaliński, zwolennik racjonalizmu i empiryzmu z dystansem odnoszący się do tradycyjnych dociekań metafizycznych. Dodajmy, że swój traktat poświęcony fizyce Doświadczenia skutków rzeczy pod zmysty podpadajacych (1765-1776) napisał wyborną polszczyzną. 
Trzeba przyznać, że Autorka właściwie doceniła wysiłki wybitnych pedagogów katolickich i różnowierczych. Oni to gwarantowali faktyczny postęp w programie szkoły, utrzymanie wysokiego poziomu kształcenia, a przez to zapewniali napływ uczniów i prymat wśród rywalizujących instytutów. Należy jednak pamiętać, że niekiedy przedkładali oni dążenia swych instytucji wyznaniowych nad interes państwa i społeczeństwa.

Z lektury rozprawy wypływa również interesujący wniosek, że w czasach, gdy szkolnictwo z trudem godziło się na recepcję najnowszej myśli naukowej, właśnie elity z urodzenia i bogate mieszczaństwo odgrywały przodującą rolę w przemianach epoki oświecenia w Rzeczypospolitej. Autorka tę konkluzję doskonale dokumentuje i analizuje. Studia nad książką poznańskiej badaczki potwierdzają tezę, że w kręgach magnackich i bogatej szlachty szybciej następowała recepcja dzieł zachodnich myślicieli. Skłaniać to może do wniosku, że dwory odgrywały przodującą rolę w przemianach doby oświecenia w Rzeczypospolitej, zwłaszcza że zakony z trudem godziły się na recepcję najnowszej myśli naukowej.

Należy podkreślić obiektywizm Doroty Żołądź-Strzelczyk w formułowaniu wniosków, będących rezultatem badań prowadzonych na bogatych i w pełni wyczerpujących materiałach źródłowych - rękopisach i starodrukach. Pozwoliły one zmodyfikować i zweryfikować wiele obowiązujących dotąd ocen dotyczących roli i znaczenia szkolnictwa Wielkopolski. Erudycyjna analiza cennych źródeł jest jasna i logiczna, nie zakłóca narracji. Monografię charakteryzuje logiczny układ i struktura, rzeczowość, przejrzystość i kompletność tez. Wpisuje się ona w nurt badań podjętych pod wpływem francuskiej szkoły Annales, co znacznie podnosi jej walory naukowe.

Należy stwierdzić, że książka Doroty Żołądź-Strzelczyk stanowi rzetelną i gruntowną syntezę zagadnienia tak ważnego dla pełniejszego poznania dziejów kultury umysłowej, edukacji, życia codziennego w Wielkopolsce. Korzystnie dopełnia obraz historii edukacji Rzeczypospolitej, ułatwia bardziej obiektywną odpowiedź na pytanie o jej miejsce w dawnej i współczesnej nam Europie.

Praca w znaczącej mierze uzupełnia dotkliwą lukę w dotychczasowym piśmiennictwie dotyczącym dziejów Wielkopolski. Zasadniczo też rozszerza naszą wiedzę o prezentowanym temacie, jest bardzo bogata pod względem faktograficznym i przekonująca w warstwie interpretacyjnej. Książkę wzbogaca 28 świetnie dobranych ilustracji. Autorka łączy solidność warsztatową i odwagę osądu zjawisk, które dalekie są od jednoznaczności, a powiązanie wyników własnych badań z historiografią europejską stanowi osiągnięcie zupełnie wyjątkowe. Autorka nie unika bowiem przedstawiania szerokiego kontekstu europejskiego, szukając analogii m.in. z systemem oświaty Niemiec czy Niderlandów. To jeden z bardzo ważnych walorów tej pracy, dopiero bowiem usytuowanie edukacyjnych poczynań w Wielkopolsce na tle europejskim pozwoliło właściwie przedstawić osiągnięcia i niedostatki szkół.

Kazimierz Puchowski 